\title{
Research on the Factors of Trade Growth between China and India
}

\section{—An Empirical Analysis Based on Constant Market Share Model}

\author{
Yan Xiao1* ${ }^{*}$ Xuedang Zheng2, Leyi Hu1, Qianying Chen1 \\ ${ }^{1}$ Central South University of Forestry and Technology, Changsha, China \\ ${ }^{2}$ Institute of International Economy, University of International Business and Economics, Beijing, China \\ Email: ${ }^{\text {xiaoyan3829@163.com }}$
}

Received 20 March 2015; accepted 11 August 2015; published 14 August 2015

Copyright (C) 2015 by authors and Scientific Research Publishing Inc.

This work is licensed under the Creative Commons Attribution International License (CC BY).

http://creativecommons.org/licenses/by/4.0/

(c) (i) Open Access

\begin{abstract}
Based on 2000-2011 trade data, this paper decomposes the trade growth factors between China and India by using Constant Market Share model (CMS). The conclusion shows that scale effect is always a major factor; the scale effect of the exports growth from China to India is manifested in the industrial finished or semi-finished products, and the competitive effect of primary products is even more significant; however, the growth of economies of scale of Indian exports to China mainly concentrates on primary products, and the competitive effect is the main factor that is restricting the growth of primary products exports, while the competitive effects of industrial finished products increase export. Adjusting the trade structure in order to meet the changes of import demand is an important means to enhance the competitiveness of export products and expand the scale of bilateral trade development. In addition, China and India Free Trade Agreement strategy should be put on the agenda, and the economic integration mechanism should be actively built.
\end{abstract}

\section{Keywords}

Sino-Indian Trade, Growth Factors, CMS Model

\section{Introduction}

As the largest developing countries in the world, both China and India pursue export-oriented economic policies, which can help them realize rapid economic growth. Influenced by factors such as long-term geopolitical conflicts, border dispute and security strategy, the trade amounts between them remain relatively small and develop

\footnotetext{
${ }^{*}$ Corresponding author.
}

How to cite this paper: Xiao, Y., Zheng, X.D., Hu, L.Y. and Chen, Q.Y. (2015) Research on the Factors of Trade Growth between China and India. Journal of Service Science and Management, 8, 569-577. 
relatively slow during a long period. The political relationship between the favored countries has been improved and developed continuously since 1990s, especially during the new century, and the bilateral economy and the trade cooperation especially the trade in goods area have entered a rapid development period and the inter-industry trades in vertical division of labor forms develop rapidly, which laid a foundation for the establishment of the economic cooperation mechanism between the two countries at the same time, and the status of economic and trade exchanges has become more significant in the Sino-Indian relationship, and is now becoming the leading force and the mainstream of the Sino-Indian relationship.

Many scholars have implemented related analysis about the Sino-Indian relationship, and the scholars can be divided into 3 groups: 1) scholars such as Wang Yongli (2004) [1], Tan Jingrong (2004) [2], Guo Jianhong (2006) [3], Zhu Jing, Chen Xiaoyan (2006) [4] who analyzed about the competitiveness, complementarity of the Sino-Indian trades, and the Sino-Indian trade relationship from the agricultural product industry, textile industry, minerals industry, other industrial manufactured goods, and concluded that the complementarity of the Sino-Indian trades was relatively weak while a considerable researchers thought that the Sino-Indian trade relationships were complementary, so the enhancement of the trade cooperation would boost the trade development of both China and India. Scholars such as Zhang Mingqiu (2004) [5], Ye Deli (2005) [6], Xu Fei (2005) [7], who made the conclusion based on the empirical analysis of the trades between China and India that the Sino-Indian bilateral trade relationship had rivalrousness to some extent, and the improvement of the trade environment and trade policies would benefit the trade cooperation between China and India. 2) Scholars such as Ni Xiangqin, Wang Xiaoying (2006) [8], Yang Wenwu, Ni Xiangqin (2007) [9], Chen Jidong, Tang Lu (1997) [10] who analyzed the trade factors and concluded that conditions such as the political stability between China and India, and the increase of the mutual visits among senior leaders lay the political foundation for Sino-Indian cooperation and also provided strong guarantee for the Sino-Indian trade; however, problems such as the high tariff, non-tariff barriers in India, the current trade channel, and the bilateral trade structure which restricted the trade development between China and India. 3) Scholars such as Li Li (2010) [11], Yang Hongling, Zhang Zhihong (2012) [12], Luo Wenbao, Zhou Jingqing (2006) [13], Yang Wenwu, Dai Jiangtao (2006) [14], Zhang Yuyan, Zhao Jianglin (2006) [15], who studied the Sino-Indian trade institutionalized construction and concluded that the conditions of establishing free trade area between China and India became gradually mature. Both China and India should encourage the regional trade arrangements in order to promote the future common interests between each other.

After summarizing the existing literature, the authors found that the research methods were simplistic, for the fact that only trade competition index, comparative advantage index and intra-industry trade index were used during the empirical process. Previous scholars tended to use their experience to judge the development of Sino-Indian bilateral trade, especially for the fact that there were rare cases of using the empirical method to analyze the bilateral trade growth factors. Thus, this paper has used Constant Market Share model (CMS) based on the general situation of the development of Sino-Indian bilateral trade since the 21th century, decomposes the general causes of Sino-Indian trade growth since $21^{\text {th }}$ century from the total trade volume level and the product classification level, and provides rational suggestions for the advancement of the bilateral trade.

\section{Development overview of Sino-Indian Bilateral Trade}

1) Trade scale enlarged rapidly, trade status enhanced obviously

In recent years, the Sino-Indian bilateral economic and trade relationship developed rapidly, now, China is the second largest trade partner of India, the $4^{\text {th }}$ largest export destination and the largest import source; and India has become the $11^{\text {th }}$ largest trade partner of China, the $7^{\text {th }}$ largest export market and the $18^{\text {th }}$ largest import source. The bilateral trade volume increased 25.36 times during ten years from the year 2000 to the year 2011. The average annual growth rate reached $36.31 \%$, much higher than the annual growth rate of Chinese foreign trade, which was $21.24 \%$ during the same period, and it was also higher than the annual growth rate of Indian foreign trade, which was $21.84 \%$. The global financial crash in 2008 had an apparent impact on the Sino-Indian economic development, which led to the decline of the economic and trade relations between them in 2009, and became the main reason for the non-liner development pattern of the increase rates of trades since 2000 . The Sino-Indian bilateral trade volume was 43.38 billion dollars in 2009, and it decreased 16.32\%, about 8.46 billion dollars compared to the 51.84 billion dollars in 2008. After that, both China and India took active measures to prevent the economic growth from further decline, and the trade decline narrowed gradually, and recovered to the level before the economic crisis. With the swift development of trades between China and India, the two 
sides have significantly increased individual status in the counterpart trade market. China accounted for 9.45\% in Indian foreign trade in 2011, which increased $7.13 \%$ compared to the $2.32 \%$ in 2000; the export status increased from $1.73 \%$ in 2000 to $5.55 \%$ in 2011; the status of China in Indian import market elevated even faster, increased from $2.79 \%$ in 2000 to $12.00 \%$ in 2011. Even though the trade status of India is relatively lower in Chinese foreign trade, but it has a stable increase trend all the time. The proportion India took in the Chinese foreign trade market increased from $0.61 \%$ to $2.03 \%$ in during these ten years, and the export proportion increased from $0.63 \%$ in 2000 to $2.66 \%$ in 2011 ; and the import proportion increased from $0.60 \%$ in 2000 to $1.34 \%$ in 2011, the trade status of India in the Chinese export market elevated relatively faster than in the Chinese import market.

2) Trade structures have improve, and overlapped obviously

In 2000, the top 5 commodities of Chinese export to India are not listed chemicals and related products, nes, machinery and transport equipment, mineral fuels, lubricants and related materials, crude materials, inedible, except fuels, manufactured goods classified chiefly by materials, and the export amounts were 409 million dollars, 326 million dollars, 268 million dollars, 221 million dollars, 214 million dollars individually, and they accounted for 26.21\%, 20.89\%, 17.15\%, 14.14\%, 13.73\% in the Sino-Indian trade export individually. In 2011, the Chinese export rates of machinery and transport equipment, not listed, chemicals and related products, nes, manufactured goods classified chiefly by materials, miscellaneous manufactured articles to India were relatively high, and the trade amounts reached 24.18 billion dollars, 10.49 billion dollars, 10.27 billion dollars, 3.96 billion dollars individually. Machinery and transport equipment are major commodities that China exports to India, which account for $47.85 \%$ of the Chinese total export amount to India; the proportions of mineral fuels, lubricants and related materials, crude materials, inedible, except fuels in Chinese export to India declined, and only accounted for 1.32\%, 1.33\%. The top 5 commodities that China imported from India in 2000 are crude materials, inedible, except fuels, manufactured goods mainly classified by raw material, not listed, chemicals and related products, nes, food and live animals chiefly for food, machinery and transport equipment, and they accounted for $37.99 \%, 25.67 \%, 17.15 \%, 9.23 \%$, 3.69\% of the imports from India. Although the absolute amount of the Chinese import from India was not that huge, the status change in the import market was really large. Crude materials, inedible, except fuels are major commodities that China imports from India, and the import amount reached 13.94 billion dollars, and the proportion even reached 59.66\%; the proportions of the products China exports to India such as manufactured goods mainly classified by raw material, not listed, chemicals and related products, nes, food and live animals chiefly for food declined gradually. They were $20.89 \%, 8.81 \%$ and $2.13 \%$ in 2011. Although currently Chinese exports to India are mainly finished products or semi-finished products, and Chinese imports are mainly primary products, the structure of the bilateral trade has improved, meanwhile, there are some intra-industry trades between China and India, and the trade structures overlap obviously between each other due to the fact that the Sino-Indian commodity structures have certain similarities during the international labor division.

3) The growing trade imbalances lead to trade friction or even trade bottleneck

The trade between China and India has experienced a surplus-deficit-surplus trend since 2000. During 2000 to 2005, the trade situation between China and India was basically in a balanced trend. Except the deficit appeared from 2003 to 2005 the import and export trades from China to India in the remaining years were surplus, and there are no obvious trade imbalance or extreme surplus or deficit problems.

During this period, the trade deficit of China was implemented in order to enlarge the economic and trade relationship between China and India, and to increase the domestic demands, so as to alleviate the deficit problem in India. Also, products made in China are difficult to enter the Indian market, especially due to the Indian high frequency of anti-dumping researches towards Chinese products, which led to the fact that during a certain period, the growth rate of Chinese export to India was less than that of the Chinese imports from India. The average growth rate of Chinese import from India was $64.92 \%$, and that of Chinese export to India was $51.07 \%$ from 2003 to 2005. Besides, Chinese steel outputs increased dramatically, and the imports of Indian mineral products such as ores increased rapidly, which became the main products that China imported from India. The situation has inversed since 2006, the trade surplus of Chinese export to India has expanded drastically, and increased from 4.304 billion dollars in 2006 to 27.164 billion dollars in 2011. The average growth rate of the surplus scale reached $48.25 \%$.

The reason that led to the trade surplus during this period was mainly because India raised the export tariff of ore continuously, so China reduced the import amounts of Indian ore while the Indian demands of Chinese 
products increased gradually, which encouraged Chinese exports to India. The huge trade deficit problems between China and India have become obvious, and have become the cause of the high frequency of Sino-Indian trade frictions, and this trade friction will become one of the bottlenecks that may restrict the development of the Sino-Indian trade in the future.

\section{Growth Factor Analysis of Sino-India Trade}

\section{1) Constant Market Share Model}

Constant Market Share model (CMS) is proposed by Tysynski for the first time, and refined by Drysdale, Jepma and Milana. It is then widely applied to the analysis of the growth source of foreign trade or the competitiveness of export products in a country (area). This model assumes that if the export competitiveness of a certain product in a country (area) remains unchanged, the market share of this product will also stay unchanged; the export changes of the product are necessarily caused by the changes in the export market scale and the changes of the product competitiveness. The initial CMS model can be presented as:

$$
e_{i}^{t}=\sum_{j} e_{i j}^{t}=\sum_{j} w_{i j}^{t} M_{i j}^{t}
$$

In the Equation (1), the $t$ means the $t$ 's period; and the $e_{i}^{t}$ presents the export amount of all the products exported to the country (area) $i$ from native country (area), while $e_{i j}^{t}$ concerns the $j^{\text {th }}$ product; moreover, the $w_{i j}^{t}$ shows the market share of the $j^{\text {th }}$ product, which is exported from native country (area) to the country (area) $i$, in the market of country (area) $i$; $w_{i j}^{t}$ is the global import amount of $j^{\text {th }}$ product in the country (area) $i$.

Differentiating the formula (1) with respect to time " $t$ ", then,

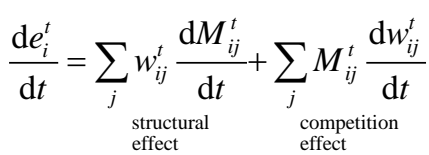

The formula (2) divides alteration of all the products exported from native country (area) to the country (are) $i$ into two parts: The first one is the structural effect, which means the change of exports in the native country (area) is due to the change of the global total exports; the second one is the competition effect, which means the change of the export competitiveness in the native country (area) results in the alteration of exports in the native country (area). If the market share in the base period was defined as the weight of the structural effect, and the total imports in the current period is used as the weight of the competition effect, then the formula (2) will evolve into:

$$
\frac{\mathrm{d} e_{i}^{t}}{\mathrm{~d} t}=\sum_{j} w_{i j}^{0} \frac{\mathrm{d} M_{i j}^{t}}{\mathrm{~d} t}+\sum_{j} M_{i j}^{1} \frac{\mathrm{d} w_{i j}^{t}}{\mathrm{~d} t}
$$

Jepma (1986) further decomposed formula (3):

$$
\Delta e=e^{1}-e^{0}=\sum_{i} \sum_{j} w_{i j}^{0} \Delta M_{i j}+\sum_{i} \sum_{j} M_{i j}^{0} \Delta w_{i j}+\sum_{i} \sum_{j} \Delta w_{i j} M_{i j}
$$

When making analysis on the single product of a single market, formula (4) can be simplified into:

$$
\underset{\substack{\Delta \\ \text { total }}}{\text { effect }} \underset{\substack{\text { scale } \\ \text { effect }}}{w_{j}^{0} \Delta M_{j}}+\underset{\substack{\text { competition } \\ \text { effect }}}{M_{j}^{0} \Delta w_{j}}+\underset{\substack{\text { cross } \\ \text { effect }}}{\Delta w_{j} \Delta M_{j}}
$$

In the formula (5), the $\Delta$ is the amount of alteration; while the $e_{j}$ and the $w_{j}$ respectively represents the quantity and the market share of the $\mathrm{j}^{\text {th }}$ product exported from native country (area) to the country (area) $i$; furthermore, the $E_{j}$ shows the total amount of the $\mathrm{j}^{\text {th }}$ product imported from the whole world in the country (area) $i$. Further decompose the amount of alteration of the $\mathrm{j}^{\text {th }}$ product exported from the native country (area) to the country (area) $i$, or the total effect $\Delta e_{j}$, into 3 effects: the first one, the $w_{j}^{0} \Delta M_{j}$, is the scale effect, which means, while the market share in the native country (area) remains unchanged, the export quantity variation caused by the demand of manufacturing or consumption in country (area) $i$, and it is also called the import demand scale effect; and the second one, the $M_{j}^{0} \Delta w_{j}$, is the competition effect, which means, while the import scale of country (area) $i$ remains unchanged, the export quantity variation caused by the influence of product 
qualities, prices or policies in the native country (area); and the third one, the $\Delta w_{j} \Delta M_{j}$, is the cross effect, which means the export quantity variation caused by the cross variation of the export structure in the native country (area) and the import structure in the country (area) $i$, and it is caused by both the scale effect and the competition effect.

\section{2) Time Treatment.}

The research range is fixed on the years from 2000 to 2011, and the purpose is to eliminate the annually fluctuation of trade, and to keep the data stable. Firstly, adopt the average value of three years, assume the years from 2000 to 2002 as the base period; take the years from 2003 to 2005 as the first period; take the years from 2006 to 2008 as the second period; and select the years from 2009 to 2011 as the third period. Secondly, deal with the statistics of bilateral basic trade between China and India as Table 1, and then compute the variation value and market share of different exporting periods. Lastly, put these data into formula 5 (CMS decomposition).

\section{3) Outcome Analysis}

\section{a) Export from China to India}

The total importing trade amount of base period in India is 48.75 billion dollar: the exporting amount from China to India reach 2.043 billion dollar, accounting for 4.19 percent of market share in South Korea. From the first period to the third period, the trade amount export from China to India increases constantly and reach the number of 40.303 billion dollar in the third period, the proportion of market share in India also increases from $6.43 \%$ in the second period, to $12.90 \%$ in the third period.

Base period-the first period: the growth of overall effect amount, exported from China to India, reaches 4.024 billion dollar; the amount of scale utility, competition utility and cross effects respectively reach 1.916 billion dollar, 1.088 billion dollar and 1.02 billion dollar, and the contribution proportion brought by such three utilities respectively reach $47.62 \%, 27.03 \%, 25.36 \%$. Among products exported from China to India, the growth of export of not listed chemicals and related products, nes, finished products, machinery and transport equipment, and miscellaneous manufactured articles, reaches 3.841 billion dollar and accounts for 95.45 percent of total export effect.

Among these products, not listed products not otherwise specified include chemicals and related products, machinery and transport equipment, and miscellaneous manufactured articles all serve a prominent function, and the contribution degree of competition effect of finished products which are categorized by their ingredient and are exported to China reaches a relatively huge level. Foods and live animals, beverages and tobacco, crude materials, inedible, except fuel, fossil fuel, lubricant oil, and other related raw material products (exported from China to India) encounter a fierce competition among Chinese market, and thus their competitive advantages constantly decrease. However, the demand of Chinese market for such type of product increase, and thus such increasing demand amount can compensate for negative effect that are caused by the decreasing competitiveness of Indian products in Chinese market. In such period, the increase in export amount of these four types of products above reaches 0.183 billion dollar, accounting for only 4.55 percent of total export effect, the contribution degree of competitive effect of different type of product to the growth of export of the same type of product respectively reach $-299.90 \%,-237.35 \%,-450.05 \%$. At the same period, the scale effects amount of these products above respectively reach 569.35\%, 1070.17\%, 859.67\%.

From the first period to the second period: the total growth of export effect amount increases to 17.269 billion

Table 1. Constant market share of Sino-Indian bilateral trade.

Unit: billion dollars, \%

\begin{tabular}{cccccc}
\hline \multicolumn{2}{c}{ Sino-Indian bilateral trade indexes } & Base year & Period 1 & Period 2 & Period 3 \\
\hline \multirow{2}{*}{$\begin{array}{c}\text { Increase of Chinese } \\
\text { export to India }\end{array}$} & Indian import & 48.75 & 94.49 & 215.32 & 312.50 \\
& Chinese export to India & 2.04 & 6.07 & 23.34 & 40.30 \\
& Market share in Indian market & 4.19 & 6.42 & 10.84 & 12.90 \\
$\begin{array}{c}\text { Increase of Indian } \\
\text { export to China }\end{array}$ & Chinese import & 252.95 & 543.04 & 957.08 & 1357.9 \\
& Indian export to China & 1.06 & 4.60 & 9.02 & 14.79 \\
\hline
\end{tabular}

Data source: calculated by the author according to the UN Comtrade Database. 
dollar. The amount of scale effect, competitive effect and cross effect respectively reaches 7758 billion dollars, 4.173 billion dollar and 5.337 billion dollar. The contribution proportions of such three types of effect respectively reach $44.93 \%, 24.17 \%$, $30.91 \%$.

In this period, products exported from China to India still concentrate on not listed chemicals and related products, nes, manufactured goods classified chiefly by materials, machinery and transport equipment, and miscellaneous manufactured articles. Such type of growth of export effects amount reaches 16,045 billion dollar, accounting for 92.91 percent of export total effect.

Although the absolute value of different effect of all kinds of products experiences a growth, the contribution degree of different effect of all kinds of products to that of all kinds of products obviously change when compared with the earlier period. The contribution degree of scale effect of manufactured goods, which are exported to China and are categorized by their components, increases among the same kind of products; such contribution degree reaches 29.81 percent, and increases by 4.97 percent when compared with the percentage of the last period (24.21\%). Furthermore, the contribution degree of competitive effect and cross effect decrease respectively from $41.30 \%$ and $34.49 \%$ in last period, to $40.26 \%$ and $30.57 \%$ in this period. In addition, the contribution degrees of scale effect of other three types of products decrease whereas the contribution degrees of competitive effect and cross effect increase. In terms of food and live animal, beverages and tobacco, because of the increasing competitiveness of such two types of products, the contribution degree of competitive effect and cross effect of such two types of products respectively reach $6.91 \%, 6.87 \%$, and $28.18 \%, 33.03 \%$. The competitive effect and cross effect of Crude materials, inedible, except fuels, fossil fuel, lubricant oil and related raw materials constantly exert a negative influence on the same type of product. Besides, the negative influence on export, brought by such two types of crude materials, inedible, except fuel, gradually decreases. However, the inhibition functions on export, which are caused by fossil fuels, lubricant oils and related raw materials, have been further deepened.

From the second period to the third period, the total effect on Indian export (16.969 billion dollar) slightly decreases when compared with the prior period. However, both the contribution amounts of scale effect and competitive effect, and their corresponding contribution rate have been improved when compared with the prior period. More specifically, the contribution degree of scale effect to growth of export reach 62.07 percent, and the corresponding contribution rate approximately reaches the number of 10.532 billion dollar. Furthermore, the descend range of cross effect is relatively large when compared with the prior period. The contribution amount is 2.001 billion dollar and the corresponding total effect contribution rate decreases from $30.91 \%$ to $11.79 \%$.

The impact of financial crisis on China is relatively large whereas exerts a limited influence on the bilateral trade. Furthermore, 1) not listed chemicals and related products, nes, 2) manufactured goods classified chiefly by materials, 3) machinery and transport equipment, and 4) miscellaneous manufactured articles: the growth of export amounts of such four types of products, which are brought by scale effect, respectively reach 1.966 billion dollar, 4.434 billion dollar, 3.35 billion dollar, 0.603 billion dollar, and their contribution degrees to correspondingly same type of product also respectively reach $55.56 \%, 174.69 \%$, $37.82 \%$, $32.71 \%$. Generally, in this period, it is obvious to observe that the export contribution degree, which is brought by competitive effect of five types of products, including food and live animals, beverages and tobacco, Crude materials, inedible, except fuels, fossil fuels, lubricants and related material, animal and plant oil, fat and wax, all gain a large improvement and respectively reach $36.57 \%, 42.30 \%, 33.91 \%$, 222.49\%, $110.82 \%$.

\section{b) Export from India to China.}

In the base period, the trade import amount of China reaches 242.951 billion dollar, and the export amount from India to China reaches 1.059 billion dollar, accounting for 0.42 percent of Chinese market share. From the first period to the third period, the total export amount of Chinese trade constantly increases, reaching 14.792 billion dollar in the third period. The proportion of this export amount to Chinese market share increases from 0.85 percent in the first period to 1.09 percent in the third percent.

Base period-the first period, the growth of export (the total effect) to China reaches 3.545 billion dollar, its scale effect, competitive effect and cross effect respectively reach 1.214 billion dollar, 1.085 billion dollar and 1.245 billion dollar, and the corresponding contribution proportions of such three types of effect respectively reach $34.26 \%$, 30.62\%, 35.12\%.

Crude materials, inedible, except fuels exported from India to China makes a relatively huge contribution to this period, and followed by manufactured goods classified chiefly by materials, Commodities and transactions not classified elsewhere in the SITC, and machinery and transport equipment, whose growth of export amounts 
respectively reach 2.205 billion dollar, 0.668 billion dollar, 0.447 billion dollar and 0.108 billion dollar, and reach 62.20 percent, 18.84 percent, 12.61 percent and 3.05 percent of export total effect in this period.

More specifically, the competitive effect and cross effect of Crude materials, inedible, except fuels and manufactured goods, classified chiefly by materials, account for a large proportion of export effect of the same type of product. The former contribution proportions respectively reach 30.83 percent and 45.07 percent, and the later contribution proportions respectively reach 47.58 percent and 31.24 percent. Food and live animal, animal and vegetable oil, fat and wax, and miscellaneous manufactured articles encounter a fierce competition in Chinese market, and thus hinder the growth of export of the same type of product. In addition, the competitive effect amount of such three types of products above is negative, and their contribution degrees respectively reach $-111.22 \%,-7.89 \%,-26.51 \%$. However, the huge demand of Chinese market for such type of product has compensated for the inhibitive influence, which is brought by India.

The first period to the second period, the total export effect to China constantly increases, reaching the number of 4.416 billion dollar. However, when the contribution degree of scale effect to export gradually increase, competitive effect and cross effect comes to decrease. The scale effect increases by 2.296 billion dollar when compared with the prior period, and its contribution degree increases by 4.522 percent. In addition, the competitive effect and the scale effect respectively decrease by 0.571 billion dollar and 0.853 billion dollar when compared to the prior period, and the corresponding contribution degree of such two types of products also respectively decrease by 18.98 percent and 26.24 percent.

In this period, although the competitiveness of Indian products decreases, huge market demand of Chinese market still can bring about the scale effect and thus can further promote the Chinese export market. The improvement range of Crude materials, inedible, except fuels is relatively huge: the export amount to China increases by 3.572 billion dollar, the contribution proportion to total export effect correspondingly increases by $80.89 \%$.

More specifically, the scale effect amount reaches 3.345 billion dollar, the export contribution rate to such type of product also increases by $93.65 \%$, a value that is closely followed by that of machinery and transport equipment closely. The export amounts of chemicals and related products, nes, and of manufactured goods classified chiefly by materials, suffer an obvious decrease. Although the scale effect increases, the competitiveness of such type of product decreases and therefore impedes the improvement of export to China. The contribution proportion of competitive effect of such two types of products to the growth of export effect of the same type of product respectively reach $-44.58 \%,-282.15 \%$; that of cross effect reaches $-28.13 \%,-100.37 \%$.

From the second period to the third period, the growth of export to China is a result, brought by joint endeavors of scale effect, competitive effects and cross effects. The contribution degrees of such three types of effects to total effect respectively reach $65.43 \%, 24.37 \%, 10.20 \%$. In this period, crude materials, inedible, except fuels, chemicals and related products, nes, manufactured goods classified chiefly by materials, machinery and transport equipment, constantly grow; in addition, fossil fuel, mineral fuels, lubricants and related materals, animal and vegetable oils, fats and waxes, miscellaneous manufactured articles also have been improved. But the growth of export amount of crude materials, inedible, except fuel decreased when compared with last period, only reaching 1.285 billion dollar and accounting for $16.29 \%$ of the total effect in this period. Because the main competitiveness declines, competitive effects appear negative and serve relatively important roles. The amount of competitive effects and cross effects reached -1.859 billion dollar and -1.365 billion dollar. In contrast, the growth of exports of food and live animals, manufactured goods classified chiefly by materials are relatively fast, and the growth of export of former reach 2.2 billion dollar, accounting for $27.89 \%$ of the total effect of the period. Such situation is caused by the economies of scale; the growth of export amount of the latter is 2.664 billion dollar, and the proportion to the total effect in this period also increase almost 2 billion dollar over the last period, accounting for $33.77 \%$ of the total effect. Such increase can mainly be attributed to the higher competitiveness. However, it is undeniable that the competitiveness of the Indian primary products, such as food and live animals, beverages and tobacco, crude materials, inedible, except fuel, obviously decreased in the Chinese market, and the inhibititive influence on export is prominent. In this period, the contribution degree of competitive effects and cross effects of three types of products to similar products was $-119.60 \%$ and $-99.66 \%,-496.61 \%$ and $-421.78 \%,-144.68 \%$ and $-106.23 \%$.

\section{Conclusions and Inspiration}

Since the new century, the bilateral trade has shown a rapid development trend between China and India. This article is based on related data of trade between China and India, and adopts CMS model to analyze the overall 
export effect and the classification product effect of the growth of export in bilateral trade. The research shows that:

1) Huge market demand for products is an important factor to increase the exports amount from China to India, especially demand for unspecified chemicals and related products, manufactured goods classified chiefly by materials, machinery and transport equipment, miscellaneous manufactured articles manufactured products and other industrial products and semi-finished products. These types of products jointly make contribution to export effect; because Chinese primary products, such as food and live animals, beveragess and tobacco, Crude materials, inedible, except fuels, fossil fuel, mineral fuels, lubricants and related materals, animal and vegetable oils, fats and waxes, improve the competitiveness of the Indian market. The competitive effect serves an increasing prominent function.

2) The pattern that India exports products to China is as similar as the pattern that China exports products to India: the scale effect plays an important role in growth of export. However, there exist differences in the standards of segmenting products. For example, although the primary products in India, such as foods, live animal, beverages and tobacco, and crude materials, inedible, except fuel take a prominent position, such type of product in India suffers fierce competition pressure from other countries, and the advantages on such type of product gradually decrease, thus the competition effect becomes more obvious. In addition, the contribution degree of scale effect of finished products, machinery and transport equipment, miscellaneous manufactured articles and other industrial products to the same type of product decrease and thus enhance the competition effects. Such situation also can illustrate that the demand of China for the same type of product of India gradually decreases.

To promote the continuing forward development of two countries, and to improve the quality and level of trade development:

1) The key to further expand the bilateral trade between China and India is to adjust and optimize the trade structures. Furthermore, the most important way to improve the overall competitiveness of exporting products is to adjust and to optimize the trade structure, and to accommodate the bilateral changing importing demands. It is essential to arrange production according to the comparison principle. And such behavior can deepen the industrial division and collaboration, can promote the adjustment of industrial structure, and can improve the capability to arrange goods structure and to adjust production capacity according to the market demand of two countries.

2) Establishing the integration of cooperation mechanism between China and India. The FTA between China and India is beneficial to the expansion of scale effect of bilateral trade. Although many detailed problems still exist in the establishment process of FTA between China and India, it is practicable to cooperate with some priority fields, which possess relatively huge cooperation potentials, such as steel, energy, and agriculture.

3) Strengthening the Intra-industry trade cooperation. Inter-industry trade is based on the comparison principle, whereas Intra-industry occurs according to scale efficiency. The potential of intra-industry trade development of finished products between China and India is huge, thus China should expand the market openness degree and promote the export of labor-incentive industry to India. Meanwhile, it is essential to improve the quality of product to a higher added-value level.

\section{Funding}

The paper was supported by fund project of education sector schedule (13YJAZH105); the decision and consultant research issue of Hunan province (2013ZZ18); Hunan province general higher institute educational reform research project (193); the phased achievement of WTO administration center Postdoctoral support project in Shenzhen in 2014.

\section{References}

[1] Wang, Y.L. (2004) Observe the Development Perspectives of Clothing Textile Trade between China and India from Terms of Competitiveness and Complementarity. World Economy Study, 8, 59-63.

[2] Tan, J.R. (2004) Comparative Study of Livestock Product Trade between China and India. International Trade Problem, 11, 39-42, 54.

[3] Guo, J.H. (2006) A Comparative Study of Foreign Trade System Reform between China and India. Contemporary Asia-Pacific Studies, 2, 18-23, 37.

[4] Zhu, J. and Chen, X.Y. (2006) The Potential Analysis of Agricultural Goods and Its Complementarity between China 
and India. International Trade Problem, 1, 40-46.

[5] Zhang, M.Q. (2004) India’s Economic Development Characteristics and Its Future. Journal of Contemporary International Relations, 10, 11-13.

[6] Ye, D.L. (2005) China and India Trade Development Potential and the Trade Policy Correction Analysis. Journal of International Economic and Trade, 5, 32-35.

[7] Xu, F. (2005) Prospect of China-India Trade and Economic Cooperation under the Background of Economic Globalization Analysis. Journal of South Asian Studies Quarterly, 2, 118-122, 126.

[8] Ni, X.Q. and Wang, X.Y. (2006) Try to Talk about the Development of the China-India Trade Cooperation Characteristics and Influencing Factors of. Journal of South Asian Studies Quarterly, 4, 91-97, 126, 127.

[9] Yang, W.W. and Ni, X.Q. (2007) Problems and Countermeasures of China-India Trade and Economic Cooperation Status. Journal of Social Science, 9, 16-24.

[10] Chen, J.D. And Tang, L. (1997) Present Situation and the Reason for Restricting the Development of Bilateral Trade between China and India Trade. Journal of South Asian Studies Quarterly, 2, 2, 14-19.

[11] Li, L. and Shao, B.J. (2008) The Establishment of the Sino-Indian Free Trade Area of China and the World Economic Impact Study. Journal of World Economic Studies, 2, 22-28, 86, 87.

[12] Yang, H.L. and Zhang, Z.H. (2012) The Analysis of Trade Expansion Effect of FTA, Based on the Gravity Model of Trade between China and India. Journal of Hebei University (Philosophy and Social Sciences Edition), 5, 4-7.

[13] Luo, W.B. and Zhou, J.T. (2006) The Obstacle and Countermeasure of Building Sino-Indian Free Trade Area. Journal of South Asian Studies Quarterly, 1, 5, 104-107.

[14] Yang, W.W. and Dai, J.T. (2006) For the Construction of Rational Understanding of Sino-Indian Free Trade Area. South Asian Studies, 1, 17-21.

[15] Zhang, Y.Y. and Jiang, L. (2006) Strategic Thinking for the Development of Sino-Indian Economic Trade Relations in the New Period. Journal of Contemporary Asia Pacific, 8, 12-20. 